\title{
ballot
}

\section{Party regulation and electoral success: The case of anti-Euro movements}

Andrea de Petris (LUISS, Itália)

adepetris@luiss.it

Assistant Professor in Comparative Public Law

LUISS Guido Carli

Viale Pola 12, 00198

Roma, Italy

P.IVA 01067231009 


\begin{abstract}
The article analyzes the new European protest political parties that want to break away from the European political-economic bloc, which have surprisingly been obtaining more voter support than forecast by political analysts. I examine the party laws of each of the countries and check for the existence of a relationship between the rules on founding new parties in each country and the success of these protest parties. For this purpose, the article is divided into three parts. In the first, I present the main characteristics of some of these parties. In the second, I summarize the types of legal regulation they need to follow in their respective countries. In the third, I analyze the results obtained by them at the polls in the European elections of May 2014.
\end{abstract}

Keywords: European Union, political parties, economic crisis of 2008

\title{
Resumo
}

Este artigo fará uma análise dos novos partidos políticos de protesto que pretendem romper com o bloco político-econômico europeu, os quais vêm, surpreendentemente, obtendo mais votos do que o previsto por analistas políticos. Examinarei as leis partidárias de cada um dos países citados no artigo e verificarei se há relação entre as normas pertinentes à fundação de partidos e o sucesso desses partidos de protesto. Para tanto, o artigo será dividido em três partes. $\mathrm{Na}$ primeira delas, apresentarei as principais características de alguns desses partidos. Na segunda, farei um resumo dos tipos de regulação legal a serem seguidas pelos partidos em seus respectivos países. Na terceira, analisarei os resultados obtidos por eles nas eleições europeias de 2014.

Palavras-chave: União Europeia, partidos políticos, crise econômica de 2008 


\section{Introduction}

Many European countries show the same pattern: protest parties are forming and criticize the established powers. Frequently they hit hard tones against the European Union and the Euro as a single currency. Populist protest parties are not a new phenomenon as such: what is new is their increasing criticism of the EU and their vehement rejection of the Euro-rescue measures ${ }^{1}$.

In Greece two new parties have recently been founded, the Drachmi Greek Democratic Movement Five Stars (abbreviated to Drachma Five Star) and the Plan B. The anti-European UK Independence Party (UKIP) worries the British Prime Minister David Cameron, while The Finns in Finland and Team Stronach in Austria reach a large number of potential voters with their critical positions. Also in Germany, the first anti-Euro party was established in 2013: Alternative for Germany (AfD), which gained over 800,000 votes in the last general elections in September 2013.

Also on the left, movements are arising which demand a complete clean up with the previous government. The performance of the Italian Five-Star Movement of Beppe Grillo at the Italian general election of 2013, or the initially rapid success of the German Pirate Party between 2009 and 2011 in regional elections, were a real surprise for many analysts and politics experts. Both parties expressed strong criticism of the European institutions and the strategies established to save the common currency.

Although they share a probably comparable political message, the new European protest parties do not receive the same levels of electoral support. On the other hand, national regulations of political parties deeply differ in the countries of the above-mentioned parties. In some cases there is a very strict discipline for founding and running a political movement; in others, no specific provision states how parties should organize themselves ${ }^{2}$. Does a relationship between these two aspects exist? Can the regulation of parties affect the chances of success of specific kinds of protest political movements like the Anti-Euro parties? This paper attempts to provide some evidence regarding this. In its first part, the paper will briefly describe the main characteristics of the above-mentioned parties. In the second part, it will summarize which kind of legal regulation must be observes in their respective countries. In the third part, it will present the results achieved by anti-Euro parties in the European elections held in May 2014. In the final remarks, the paper will consider if it is possible to identify a certain mutual influence between party legislation and voters' preferences for the Anti-Euro parties.

\section{Most recently arisen anti-Euro populist parties \\ 1.1. Austria: Team Stronach}

The Austro-Canadian entrepreneur Frank Stronach wants to shake up the political landscape in Austria. In the 1950s, the 80-year-old wandered to Canada, where he made a career with his "Magna International" auto-supply empire. His party, Team Stronach für Österreich (Team

1. K Grabow/F Hartleb, Europe - No, thanks? Study on the Rise of Right-Wing and National Populist Parties in Europe, Konrad Adenauer Stiftung/Center for European Studies, (2014), avail. at: http:// martenscentre.eu/sites/default/files/publication-files/kas_36200-544-2-30.pdf [last access 11.3.2015].

2. S Bukow/T Poguntke, «Innerparteiliche Organisation und Willensbildung», in: O. Niedermayer (ed.), Handbuch Parteienforschung, Heidelberg, Springer (2013), pp 179-209. 
Stronach for Austria) - TS, was founded in the autumn of 2012, and is made up of defectors (former disappointed voters) from the right-wing populist camp: from the Freibeitliche Partei Österreichs - FPÖ (Liberal Party Austria) and from the Bündnis Zukunft Österreich (Alliance Future Austria) - BZÖ, the party of the late right-wing populist Jörg Haider.

Stronach stresses in his campaign "values and fairness" and warns against the decline of Europe. To prevent this, every country should get its own Euro, setting the German currency as general reference for the exchange rate. Stronach wants less influence from Brussels, rejects any form of centralization and has insulted journalists during interviews as stupid ${ }^{3}$. He wants more power for someone like himself, who has proven as a self-made billionaire that he can multiply money. And what happens in the economy is possible also in politics, believes Stronach.

In the Austrian election year of 2013, Team Stronach was the winner. In the state elections in Lower Austria the party won 9.8 percent, whilst in Carinthia 11.3 percent and 8.3 percent in Salzburg. In the national Parliamentary elections on September 29, the newcomer Team Stronach gained $5.73 \%$ of the votes and 11 seats in the National Council. The party attracts mainly former FPÖ, BZÖ and the traditional Österreichische Volkspartei (Austrian People's Party) - ÖVP voters from the middle class in the small towns ${ }^{4}$. Voters see Stronach as a hope to gain more transparency in their country, since a number of political corruption cases have been uncovered in Austria in recent years ${ }^{5}$. However, according to surveys in March 2014, Team Stronach should not obtain more than 2\% of the votes in the next European Elections, which would not allow the party to gain seats in Strasbourg.

\subsection{Finnland: The Finns}

The economic crisis helped The Finns (Perussuomalaiset) - formerly The True Finns - unexpectedly to rise: in 2011, the party was able to win 19.1 percent of votes in the parliamentary elections and was charged with 39 seats as the third strongest party in parliament ${ }^{6}$. Four years earlier, the party which was founded in 1995 gained only 4 percent of the votes. This success is largely due to the leader, Timo Soini, who is acknowledged as a very talented speaker ${ }^{7}$. With unique slogans such as "Where the EU is, there is the problem" or "It is outrageous that we pay their debts", he beats the drum for his party.

According to Soini, "honesty, hard work and friendship" are the solid virtues of the party. Despite the low percentage of foreigners in Finland (about 3 percent), The Finns party advo-

3. "Herr Stronach, ich bin kein Staatsangestellter" - Transkript vom Interview mit Armin Wolf und Frank Stronach in der ZIB 2 (9 April 2013), avail. at: http://neuwal.com/index.php/2013/04/09/transkriptarmin-wolf-im-gesprach-mit-frank-stronach-orf-zib2-9-april-2013/ [last access 11.3.2015].

4. «Mobilisierung am Rande von Wien», avail. at: http://news.orf.at/stories/2169730/2169723/ [last access 11.3.2015].

5. S Müller, «Die Kosten der Korruption», Zeit Online 12 April 2012, avail. at: http://www.zeit. de/2012/16/A-Korruption [last access 11.3.2015].

6. D Arter, «Taking the Gilt of the Conservatives' Gingerbread: The April 2011 Finnish General Elections», 34 West European Politics (2011), pp 1284-1295.

7. C. Mars, «The Rise of Right-wing Populism in Finnland: The True Finns», Transform! 8/2011, avail. at: http://transform-network.net/journal/issue-082011/news/detail/Journal/the-rise-of-right-wing-populism-in-finland-the-true-finns.html [last access 11.3.2015]. 
cates a restriction of the asylum laws. The party also rejects gay marriage, is against extramarital sex and wants to cut financial aid for the development of foreign countries ${ }^{8}$. The Finns party is also against the EU, although Soini has been a member of the European Parliament since 2009. He also speaks fluent Swedish, yet is against compulsory Swedish lessons in schools?.

The Finns want to give a voice to the "little guy", meaning all those who see themselves as losers of the EU. They make the European Union responsible for the consequences of globalization, the associated closures of factories and enterprises, and for cutbacks in the social sector ${ }^{10}$. According to Statistics Finland, the party's electorate is derived from rural areas with high unemployment rates and low education. In the autumn of 2012, with 12.3 percent of the votes in the municipal elections, the Finnish right-wing populists were able to more than double their share in the previous elections of 2008, when they achieved 5.4 percent of the preferences at a local level ${ }^{11}$. The last surveys about the preferences of Finnish voters for the coming European elections credit The Finns party with between 16 and 18 percent of the votes, which would confirm their actual position as the third political movement in terms of consent in Finland.

\subsection{France: Front National}

The Front National (FN) was for long time known by the French electorate as a radical and racist extreme-right party, since its foundation in 1972. This perception rapidly changed when the founder of the party, Jean-Marie Le Pen, left the leadership of the movement to his daughter Marine in January $2011^{12}$. Opinion polls showed that the party's popularity increased under Marine Le Pen, and in the 2011 local elections the Front National won 15 percent of the votes, increasing by over 10 percent on the 4.5 preferences obtained in the previous elections of $2008^{13}$. Nevertheless, the character of the French electoral system allowed the party to win only 2 of the 2,026 available in those elections. In the 2012 presidential election, opinion polls showed Marine Le Pen as a serious challenger, while some surveys even sugges-

8. «True Finns publish Election Manifesto», 25 February 2011, avail. at: http://yle.fi/uutiset/true_finns_ publish_election_manifesto/2391059 [last access 11.3.2015].

9. D Arter, «Analysing “Successor Parties”: The Case of the True Finns» 35 West European Politics (2012), pp 803-825.

10. T Raunio, «The Finns: Filling a Gap in the Party System», in: K Grabow/F. Hartleb (eds.), Exposing the Demagogues. Right-Wing and National Populist Parties in Europe, Konrad Adenauer Stiftung/Center for European Studies (2013), pp 133-160, avail. at: http://www.kas.de/wf/doc/kas_35420-544-2-30. pdf?131104120553 [last access 11.3.2015].

11. Statistics Finnland, Confirmed result: Coalition Party retained its position as the largest political party, True Finns the biggest winners in Municipal elections 2012, 2 November 2012, avail. at: http://tilastokeskus.fi/til/kvaa/2012/kvaa_2012_2012-11-02_tie_001_en.html [last access 11,3.2015].

12. M Balent, «The French National Front from Jean-Marie to Marine Le Pen: Between Change and Continuity», in: K Grabow/F Hartleb (eds.), Exposing the Demagogues, cit., pp 160-186, avail. at: http://www.kas. de/wf/doc/kas_35420-544-2-30.pdf?131104120553 [last access 11.3.2015].

13. Résultat des élections Cantonales 2011. French Interior Ministry, 26 May 2011, avail. at: http://www.interieur.gouv.fr/Elections/Les-resultats/Cantonales/elecresult_cantonales_2011/(path)/cantonales_2011/ [last access 11.3.2015]. 
ted that she could win the first round of the election ${ }^{14}$. Despite the fact that Le Pen actually came third in the first round, with 17.9 percent of the preferences she managed to achieve the best result ever for the FN. In the municipal elections held on 23 and 30 March 2014, local lists officially supported by Front National won Mayors in 12 cities, whilst in cities of over 1,000 inhabitants the party obtained 1,546 councillors in the first and 459 in the second level of local government ${ }^{15}$.

Many scholars described the FN ideology as authoritarian, nationalistic, and populist ${ }^{16}$. Nevertheless, the party changed significantly since its foundation, and has pursued the principles of modernization and pragmatism, adapting to the variable political mood. At the same time, its propaganda has progressively influenced traditional political parties, although the FN too has shifted from extreme-right to center-right position in recent times ${ }^{17}$. In the most recent campaigns, Marine Le Pen has expressed harsh criticism of the EU and Euro, demanding a reduction of influence by European institutions and a return to a central role of national authorities.

The most recent opinion polls credit the FN with up to 24 percent of the votes in the coming European elections, which would make the party of Marine Le Pen the second or, according to some surveys, even the first political force in France at the moment.

\subsection{Greeceः Drachma Five Stars and Plan B}

Two parties have been founded in the last two months in Greece, advocating the withdrawal from the EU: Plan B of the links politician Alekos Alavanos and Drachma Five Stars, created by economist Theodore Katsanevas. Both party leaders are very well known personalities in business policy: Katsanevas , 66, was a functionary of the Panhellenic Socialist Movement (Pasok); Alavanos , 63, led the Left Alliance SYRIZA from 2004 to 2008. He left the party in 2011 and formed the Front of the Solidarity of the Revolution. The party flopped, and now he is attempting with the new movement Plan $\mathrm{B}^{18}$.

Although the Drachma is worth about 0.00293 Euros, and is therefore not really a valuable coin, it is the logo of the anti-Euro party Drachma. Its subtitle "Greek Democratic Five Star Movement" refers to the five stars which stand for the proposals formulated by the five goals of the party: termination of credit agreements with international donors, an exit from

14. France 24, «New poll shows far right could squeeze out Sarkozy», 23 April 2011, avail. at: http://www. france24.com/en/20110421-marine-le-pen-france-opinion-poll-presidential-election-sarkozy-strausskahn/ [last access 11.3.2015].

15. Frontnational.com, «Elections municipales 2014: Le Front National gagne 12 villes, fait élire 1546 conseillers municipaux et 459 élus dans les intercomunalités!», avail. at: http://www.frontnational. com/2014/03/elections-municipales-2014-le-front-national-gagne-12-villes-fait-elire-1546-conseillersmunicipaux-et-459-elus-dans-les-intercommunalites/ [last access 11.3.2015].

16. J G Shields, The extreme right in France: from Pétain to Le Pen, London, Routledge (2007), p 310.

17. B Beauzamy, «Explaining the Rise of the Front National to Electoral Prominence: Multi-Faceted or Contradictory Models?», in: R Wodak/M KhosraviNik/B Mral (ed.), Right-Wing Populism in Europe: Politics and Discourse, London/New York, Bloomsbury (2013), pp 177-190.

18. E Gamperl, «Europas neue Anti-Parteien», Zeit Online, 23/3/2013, avail. at: http://www.zeit.de/ politik/ausland/2013-05/protestparteien-europa-antieuro [last access 11.3.2015]. 
the Euro, economic growth, national dignity and social justice. Katsanevas wants the southern European countries to leave the EU. Plan B's program includes the requirement to set the measures addressed to reduce the Greek public debt. Both parties also want to reintroduce the drachma as the Greek currency ${ }^{19}$.

Alavanos relies on optimism and believes that up to 50 percent of the Greeks will vote for his party - in his view, those who are for the departure from the Euro zone. Great success of both parties on this basis is not in sight. According to a survey of 2013, the majority of Greeks - 62.7 percent - want to maintain the Euro, apparently at all costs. Since the next parliamentary election is planned in the spring of 2016, the next significant test to evaluate the strength of Drachma and Plan B will be the European Elections of May 25, 2014.

\subsection{Germanyः Alternative für Deutschland and Piratenpartei}

Virtually out of nowhere, another new party formed in Germany after the Pirates. The right-wing Alternative für Deutschland (Alternative for Germany) - AfD, was founded in late 2012 by the publicists Konrad Adam and Alexander Gauland and the economist Bernd Lucke. The former $C D U$ members were convinced that they could overcome the 5 percent hurdle in the German general election in the autumn of 2013. On the one hand, the results of the elections finally disappointed them, since AfD achieved 4.7 percent of the votes at a federal level, not enough to overcome the 5 percent threshold and gained no seats in the German Bundestag. On the other hand, the party was able to attract the preference of 810,915 voters in its first attempt in a general election, an extraordinary result for a newcomer in a usually steady party system like the German one $e^{20}$.

So far, the party has gained attention exclusively with its anti-European position. Some do not need the Euro, the others only suffer because of it, it says in the AfD campaign program. The party advocates the reintroduction of the Deutsche Mark, or will at least create smaller regional currency associations. In addition, the more than 10,000 supporters of the conservative party call for the exclusion of southern countries from the European Union ${ }^{21}$.

According to a representative survey by the pollster YouGov for ZEIT ONLINE, AfD has the largest potential voters among former FDP and the Left Party voters and the right-wing conservatives of the Union. Overall, 27 percent sympathize with the Euro-critical grouping. Currently, surveys on the preferences in the coming European elections show that AfD could gain between 5 and 8 percent of the votes, a result which would confirm the positive trend of the party since its first appearance in 2013.

19. M Mavrozaharakis/S Tzagkarakis/A Kamekis, «Greek Modern Populism in its European Context», Open Democracy, 4 November 2013, avail, at: http://www.opendemocracy.net/can-europe-make-it/manolis-mavrozaharakis-stelios-tzagkarakis-apostolos-kamekis/greek-modern-populis [last access 11.3.2015].

20. D Siemens, «No Experiments? The German Federal Elections 2013», University College London, European Studies, avail. at: http://www.ucl.ac.uk/european-institute/highlights/german-elections [last access 11.3.2015].

21. F Decker, «Das Parteiensystem vor und nach der Bundestagswahl 2013», 11 Zeitschrift für Staats- und Europawissenschaften, (2013), pp 323-342. 
The first Pirate Party was established in 2006 in Sweden and fought for a "free" Internet and against strict copyright regulations ${ }^{22}$. The Pirates see themselves as pioneers of a digital revolution. Meanwhile, similar movements have arisen in more than 40 other countries - such as the German Pirate Party, founded in 2009, which is the most successful after the Swedish one. In the German Pirate party it is possible to find entirely different political directions: the party would not like to be classified in the left-right scheme ${ }^{23}$.

For a long time the party had the charm of a new movement, the anti-politics organization, the "being against" trend. With this approach, the German Pirate Party was surprisingly drawn into the Berlin House of Representatives in $2011^{24}$, while the Swedish Piratpartiet sent a representative to the EU Parliament in 2008. Meanwhile, the German movement is losing popularity - not least because of competition from a new protest party: the previously-mentioned AfD. In order to re-establish itself in the general election of 2013, the German Pirates set out a detailed program: in addition to its basic theme regarding a more liberal network policy, it advertised for binding referenda and demanded, amongst other things, the abolition of the conventional concept of family. With regards to Euro policies, the German Pirates avoided clear refusing positions in the past: in its European Parliament Electoral program they nevertheless plead for the establishment of a constituent assembly aimed to reshape also the European political guidelines on finance and common currency ${ }^{25}$.

The Pirate Party has scored so far, especially at first and protest voters. Currently, it is suffering a significant loss in consent at the polls: at the beginning of 2013 the party failed to overcome the 5 percent hurdle in the state elections in Lower Saxony. The general elections which followed in September 2013 did not provide any recovery, with the Piratenpartei able to gain only 2.2 percent of the preferences: not enough to obtain a seat in the new Bundestag. The last available surveys on the possible results of the polls at the next European elections forecast a very low level of preferences for the German Pirate party.

\subsection{Italyः Movimento 5 Stelle}

The Movimento 5 Stelle (Five Stars Movement) - M5S, was officially launched in Italy as a national party on October 4, 2009 by Giuseppe "Beppe" Grillo, who is actually a comedian by profession. With his "Grillini" (little crickets) he was, within three years, the third strongest party of the Italian Parliament ${ }^{26}$. He began his political involvement with an Internet blog in

\footnotetext{
22. H Bartels, «Die Vorgeschichte: die Urheberrechtsdebatte und die schwedische Piratpartiet», in: O Niedermayer (ed.), Die Piratenpartei, Heidelberg, Springer (2013), pp 15-28.

23. M Seemann, «Plattformneutralität - das politische Denken der Piraten», in: C Bieber/C Leggewie (ed.), Unter Piraten. Erkundungen in einer neuen politischen Arena, Bielefeld, Transcript (2012), pp 91-99.

24. C Koschmieder, «Die Piratenfraktion im Berliner Abgeordnetenhaus», in: O Niedermayer (ed.), Die Piratenpartei, cit., pp 213-235.

25. Geld. Die Neue Spielregeln. Diskussion mit Christian Felber, avail. at: https://www.piratenpartei. de/2014/04/13/geld-die-neuen-spielregeln-diskussion-mit-christian-felber/ [last access 11.3.2015].

26. R Biorcio/P Natale, Politica a 5 Stelle. Idee, storia e strategie del movimento di Grillo, Milano, Feltrinelli (2013), pp 77-98.
} 
which the 64 -year-old complains about corruption and Italian politics ${ }^{27}$. Grillo is not a professional politician, as his attitude in public meetings shows. He calls his opponents simply "Butt" and strictly refuses as a member of the opposition any form of compromise with other political parties ${ }^{28}$.

The movement sees the future of politics in the Internet, where all citizens take decisions jointly ${ }^{29}$. Thus, the Grillini want to abolish the classic professional politician. The movement wants a vote on Italy's fate in the EU and vehemently rejects the European austerity program. It focuses on environmental issues, the redistribution of income and the cut of executive pay as party financing ${ }^{30}$.

The Five-star Movement appeals to a broad spectrum of voters. The Grillini are a reservoir of the disillusioned left, Silvio Berlusconi and Lega Nord voters, and all those who are hoping that things will change after 20 years of disappointing government. One in four Italians chose the party in the parliamentary elections in February 2013. They are most popular with young voters: 16 percent were under 22 years old. The movement has recently shown ferments and turbulences: not all party members agree with the hierarchical leadership of the comedian. The most recent surveys show the M5S likely to gain between 22 and 25 percent of the votes in the next European Elections, which could make it the second most-voted party in the competition.

\subsection{United Kingdom: United Kingdom Independence Party}

Nigel Farage and his United Kingdom Independence Party (UKIP) are considered to be the terror of the established parties in Britain. As an anti - Euro party, UKIP celebrated one triumph after another in the regional elections of 2013. Since 1999, Farage has sat in the European Parliament, and he is himself a former supporter of the Conservative Party. This protest party has also suffered repeatedly from discordant notes: UKIP parted from a few members who wanted to set fire to mosques or who posted mocking photos with Hitler on social media sites ${ }^{31}$.

Initially dismissed by Prime Minister David Cameron as a weird movement, UKIP today influences the agenda of all mainstream parties. With a bill providing for an EU referendum

27. J Bartlett/C Froio/M Littler/D McDonnell, «Social media is changing politics across Europe... New political Actors in Europe: Beppe Grillo and the M5S», London, Demos, 2013, avail. at: http://www. demos.co.uk/files/Beppe_Grillo_and_the_M5S_-_Demos_web_version.pdf?1360766725 [last access 11.3.2015].

28. R Vignati, «Beppe Grillo: dalla Tv ai palasport, dal blog al Movimento», in: P Corbetta/E Gualmini (ed.), Il Partito di Grillo, Bologna, Il Mulino (2013), pp 29-63.

29. L Mosca/C Vaccari, «Il Movimento e la Rete», in: P Corbetta/E Gualmini (ed.), Il Partito di Grillo, cit., pp 169-196.

30. G Passarelli/F Tronconi/D Tuorto, «Dentro il Movimento: organizzazione, attivisti e programmi», in: $\mathrm{P}$ Corbetta/E Gualmini (ed.), Il Partito di Grillo, cit., pp 123-167; G Santoro, Un Grillo qualunque. Il Movimento 5 Stelle e il populismo digitale nella crisi dei partiti italiani, 2nd ed., Roma, Castelvecchi, (2013), pp 37-79.

31. N Watt, «Ukip in fresh Nazi row after candidate Photoshops Hitler image», The Guardian, 1 May 2013, avail. at: http://www.theguardian.com/politics/2013/may/01/ukip-nazi-row-photoshops-hitler [last access 11.3.2015]. 
in 2017, Cameron wants to come closer to the EU-critics. In addition to an EU exit and increased spending on military forces, police and prisons, UKIP also claims that migrants should remain without social assistance or other government support for five years. In addition to this, the party is against wind turbines and gay marriage ${ }^{32}$.

UKIP takes its voters from the conservative milieu. In opinion polls, it is currently at 16 to 17 percent, with more consent than the Liberals and only 13 points behind the Conservative party. So far they have not managed to send a deputy to the British House of Commons, most likely because of the particularly high hurdle foreseen by the British electoral system. UKIP has managed to double its votes compared to the last local elections four years ago, and currently holds 140 seats in local assemblies. In the next European elections in 2014, UKIP wants to overtake the Conservatives.

\subsection{European perspectives}

Across Europe, protest movements are on the rise and cost established parties percentage points or even their participation in government. They differ from the protest parties which were active in the mid-1990s in the parliaments: Jörg Haider, Geert Wilders and Jean-Marie Le Pen were mainly concerned with the exclusion of minorities. Their agendas were crime, unemployment and immigration. The new political protest parties, however, want to change the political system and frequently focus their anger against the European Union, financial markets and the establishment.

Their main argument - whether right or left - against the European Union is of an economic nature. According to the political scientist at the University of Mainz, Kai Arzheimer, they warn of the "financial solidarity within the EU" and want to protect the taxpayers' money. On the one hand, the aim of the northern European populists is often not the exit the EU, but much more a split between the rich North and the poor South of Europe. On the other hand, the southern protest parties refuse to submit to the rules of the North and consider the EU financial regulations as an undeserved burden for their national economies.

At the top in almost all the above-mentioned protest parties, there is a "closer to the people" leader who purports to speak to the honest taxpayers from the soul. But there are not only political newcomers in the protest parties. Bernd Lucke, the initiator of the AfD, was a member of the CDU for 33 years, until he resigned from the party in protest against the Euro rescue policies supported by the Christian Democratic Union. The Briton Nigel Farage was for many years a faithful member of the Conservative Party, before he set up the UK Independence Party, in clear dissent from his party about European commitments. Even if he was never inscribed in any political party, the M5S leader Beppe Grillo was considered for years closer to left-wing positions and regularly put Silvio Berlusconi in the middle of his critical comments before he decided to create his own political movement in protest against all established parties on the left as well as on the right of the Italian political spectrum.

Often, the protest parties refuse any form of political etiquette: Nigel Farage asserted during a plenary session that the EU Council President, Herman Van Rompuy, had the "charisma of a washcloth", while Beppe Grillo also often tends to insult his opponents. Frank

32. R Ford/M Goodwin, Revolt on the Right. Explaining support for the radical right in Britain, London and New York, Routledge (2014). 
Stronach speaks reluctantly with the media and, when he does, he willingly defines journalists as incompetent. The Pirates behave atypically for politicians too, since they often render internal conflicts public through social media.

Their voters find the protest parties in all parts of society. According to Arzheimer, Anti-Euro movements can especially attract previous non-voters and those who are disappointed by the traditional parties. A survey conducted in 2013 in Germany showed that both the Pirates ( 84 percent) and the AfD (68 percent) were chosen by citizens mainly because of their dissatisfaction with other parties. Nevertheless, the survey also indicated that the number of supporters who chose the AfD because of its thematic orientation were double (16 percent) the ones who preferred the Pirates for the same reason, the latter being elected primarily as a protest in itself ${ }^{33}$.

\section{Party regulation ${ }^{34}$}

\subsection{Austria}

The Austrian Constitution of 1920 already contained a minimal reference to political parties. The Federal Constitution of 1945 contains several articles mentioning political parties, increasing from four in the original version of the Constitution to sixteen after the latest constitutional amendment of 2007. The main topics of the constitutional parties discipline regard procedural and administrative regulation in the parliamentary, the electoral and the governmental domains.

After many Austrian political parties have fallen upon hard times due to various cases of corruption in the recent past, the Austrian Parliament adopted a new law on political parties in $2012^{35}$. It affects not only the parties which collect public financing, but all parties in general, campaigning groups and specific organizational groups connected to political parties. The 2012 Party Law, which concentrates mainly on the regulation of party financing, obliges all parties to submit an annual accounting statement of revenues and expenses, controlled and confirmed by two different auditors. On the one hand, the new regulation pursues wider transparency in the accounting of political parties, rewarded with an increased level of their public financing ${ }^{36}$. On the other hand, the law merely defines a political party as "a permanently organized association, which expresses a joint activity aimed at influencing the public

\footnotetext{
33. E Gamperl, «Europas neue Anti-Parteien», cit.

34. Reference on Party Law in European countries are summarized in a very precise and detailed Database on the website "Party Law in Modern Europe", avail. at: http://www.partylaw.leidenuniv.nl/laws [last access 11.3.2015].

35. Bundesgesetz über die Finanzierung politischer Parteien (Parteiengesetz 2012 - PartG), BGBl. I Nr. 56/1012, avail. at: https://www.ris.bka.gv.at/GeltendeFassung.wxe?Abfrage=Bundesnormen $\&$ Gesetzesnu mmer $=20007889$ [last access 11.3.2015].

36. S Lenzhofer, «Die neue Parteienfinanzierung: Mehr Transparenz im Tausch gegen höhere staatliche Zuwendungen», avail. at: http://www.jusportal.at/die-neue-parteienfinanzierung-mehr-transparenz-imtausch-gegen-hohere-staatliche-zuwendungen_stephan-lenzhofer/ [last access 11.3.2015].
} 
decision-making process, in particular by participating in elections to general representative bodies and the European Parliament, and deposits its Statute at the Federal Ministry of the Interior ${ }^{\prime 37}$, paying very little attention to other aspects of party regulation and providing no rules about parties' internal organization.

\subsection{Finland}

The new Finnish Constitution of 1999 contains two articles on political parties, which in both cases define their electoral functions: regarding the nomination of candidates for the parliamentary elections ${ }^{38}$, and the nomination of candidates for the election of the President of the Republic ${ }^{39}$.

The first regulation on political parties was issued already in $1969^{40}$, and was not just one of the first provisions of this kind, but also offered very detailed rules about parties' organization, making Finland a very unusual case in terms of parties' legal discipline. After the latest amendment of the Finnish party law in 2010, if political parties want to be officially recognized as such, they must send their application to a Party Register held by the Ministry of Justice and fulfil a number of conditions: pursuing to influence State matters; gaining support from at least 5,000 citizens with voting rights; guaranteeing democratic principles to be respected in their decision-making processes and internal activities; drafting a political program. The actual law also requests some materials for party registration: a copy of the rules and regulations in force and the party program must be inscribed in the Party Register before being internally enforced. Political parties are deleted from the Party Register if they do not obtain at least a parliamentary seat in two consecutive parliamentary elections.

Finland also has a very detailed regulation of party finance. The above-mentioned Act of 1969 established State funding to political parties, included provisions on its allocation procedures and established the duty for parties to keep and to disclose their financial records. Public grants are given to parties to cover their expenses in public activities, in proportion to the number of parliamentary seats they obtained in the latest parliamentary elections. Parties without parliamentary representation, therefore, do not obtain any public funds. State funds are instead withheld if a party fails to fulfil any of the obligations laid down by the law.

In 1969, Finland also adopted a specific party finance law $^{41}$, which foresees no restriction on the sources of private funding and on the relative amounts of the donations. Anonymous foreign contributions are therefore allowed, and there is no limit on the parties' expenditures. In order to ensure their effective transparency, the Political Parties Act obliges parties to keep books of their finances and to send their financial records to the Ministry of Justice,

\footnotetext{
37. $₫ 1$ par. 2 Parteiengesetz.

38. Art. 25.

39. Art. 54.

40. Act on political parties, 10/1969, avail. at: http://www.finlex.fi/fi/laki/kaannokset/1969/en19690010. pdf [last access 11.3.2015].

41. Decree on Subsidies to support the activities of Political Parties, 97/1969, amended by Law 27/1973 and by Law 97/1990.
} 
whilst incomes and expenses regarding electoral campaigns must be exhibited separately. A further provision, the Act on the Disclosure of Election Financing ${ }^{42}$, was issued in 2000 in order to make the financing of electoral campaigns even more transparent. According to this act, candidates must reveal the full amount of each donation they obtain, and must make public the donor's identity in case the donation exceeds a given threshold. Political parties also have free air-time granted by the Finnish Broadcasting Company, whilst their parliamentary groups have already been financed since 1967.

\subsection{France}

The Constitution of 1958 mentions political parties in art. 4, which defines political parties as freely-formed organizations instrumental in the exercise of suffrage whose activities must respect the principles of national sovereignty and democracy. This article was amended in 1999, when a further paragraph imposed that further statutes passed by the national Parliament must "guarantee the expression of diverse opinions and the equitable participation of political parties and groups in the democratic life of the Nation".

Despite of this high attention to the public role of political parties in the Constitution, France has not adopted a political party law. The only national provision on political parties is the law on the financial transparency of political life, passed in 1988, whose Title III includes references to political parties ${ }^{43}$. In order to obtain public funding, political parties must present candidates who have each gained at least 1 per cent of the votes in at least 50 electoral districts. The law assigns a total amount for the public finance of political parties, which is distributed in two separate steps. The first part is assigned in proportion to the number of votes received during the first round of parliamentary elections, whilst the second portion is distributed to those political parties that achieved parliamentary representation in proportion to the number of MPs declaring their affiliation to one party. Further provisions of the law rule further obligations which must be observed by parties in order to be eligible for public funding and election reimbursements, aimed at granting full transparency of parties expenditures and incomes. A specific "Commission on Campaign accounts and Political Party Financing" is responsible for the supervision of the financial duties of political parties and their candidates. Political parties which receive public and private funding must keep annual accounting records, which have to be certified by two auditors and submitted to the Commission. This, in turn, is entitled to cut public funding for the next year to those parties whose accounting records show mistakes or infringements.

Therefore, if the public funding regulation of political parties is quite strict, the fact that France knows no specific provision on the internal organization of political movements makes their creation relatively simple. Most of the current political parties have been created under

42. Available at: http://www.finlex.fi/fi/laki/alkup/2008/20080604 [last access 11.3.2015].

43. "Dispositions relatives aux parties et groupements politiques et à leur financement", avail. at: http:// www.legifrance.gouv.fr/affichTexte.do?cidTexte=LEGITEXT000006069061 [last access 11.3.2015]. 
the legal status of an association. Thus, it only takes five minutes and it just needs two people to go to the Prefecture and to declare the aim of the association ${ }^{44}$.

\subsection{Germany}

The German Basic Law of 1949 is by far the most detailed European Constitution regarding the regulation of political parties. Its art. 21 defines political parties as instruments of the formation of the political will of the people, establishing important rules on the political parties' activity and identity. It declares unconstitutional and compulsorily dissolves those parties "which, by reason of their aims or the behavior of their adherents, seek to impair or destroy the free democratic basic order or to endanger the existence of the Federal Republic of Germany". This same article, moreover, states that the political parties' internal organization "must conform to democratic principles", and that parties must "publicly account for their assets and for the sources and use of their funds as well as assets".

Germany was the first European country to pass a law on political parties in $1967^{45}$, which was subsequently amended in 2004 and 2011. The German party law contains eight main sections. Section I introduces general provisions concerning political parties, such as their constitutional status and functions (art. 1), their definition ( $\operatorname{art} .2$ ), the right of parties to institute legal proceedings (art. 3), rules on the parties' names (art. 4), and the establishment of the principle of the equal treatment of political parties (art. 5). Section II regulates the parties' internal organization. According to art. 6, political parties must have written statutes and programs including details on their requirements for membership as well as members' rights, on the general organization of the party, on the composition and powers of the internal party bodies, on the forms and the timelines for the convocation of the general assembly, and on the functions of the parties' executive organs. Detailed provisions on the political parties' bodies, on their composition and on the frequency of their meetings, are included in articles 8-13. Political parties in Germany must establish internal Arbitration Courts, "to settle and decide on disputes between the party or a regional branch and individual members, as well as on disputes over the interpretation and implementation of the statutes" (art. 14). The German party law also disciplines the internal voting procedures of political parties (art. 15), and prescribes secret ballots for the nomination of candidates for elections.

Section VII regulates the implementation of the banning of parties which have been declared unconstitutional according to article 21 of the Basic Law. Under art. 32, the supreme authorities of the Länder have the unrestricted right to give instructions in order to adopt any measures needed to enforce the judgment ordered by the Federal Constitutional Court.

Since Germany chose to not adopt a specific party finance law, the regulation of the political parties' financial matters, including provisions on state funding of political parties, on accounting, and on the private donations to political parties, are foreseen in the law on

44. B Jouan, «Financing of political parties and electoral campaigns in France. The role of the French National Commission on campaign accounts and Political Party Financing (CNCCFP)», Legal service CNCCFP, avail. at: www.transparency.hu/uploads/docs/francia.doc [last access 11.3.2015].

45. Parteiengesetz (PartG), Gesetz über die politischen Parteien in der Fassung der Bekanntmachung vom 31. Januar 1994 (BGBl. I S. 149), zuletzt geändert durch Artikel 1 des Gesetzes vom 23. August 2011 (BGBl. I S. 1748), avail. at: http://www.bundestag.de/bundestag/aufgaben/rechtsgrundlagen/pg_pdf.pdf [last access 11.3.2015]. 
political parties. Section IV, V and VI of the party law establish therefore the rules of public funding of political parties, the accounting requirements, and the penal provisions for financial transgressions ${ }^{46}$. The law on political parties also regulates private contributions to political parties. According to art. 25, anonymous as well as foreign donations to political parties above a specified threshold, are not allowed, whilst private donations in cash are not admitted over the 1,000 Euros limit.

The law on political parties specifies the parties' accounting and disclosure obligations, implementing the provision of art. 21 of the Basic Law which obliges political parties to "publicly account for their assets and for the sources and use of their funds as well as assets". Every year, political parties must present an audited statement of accounts to the President of the German Bundestag, which must include information on party income and expenditure as well as a statement on the parties' properties and liabilities. If the statement of accounts is correct, the President of the German Bundestag fixes the rate of public funds to be allocated to each individual party, and publishes the parties' statements of accounts as a Bundestag printed paper in order to make them public.

\subsection{Greece}

Currently, the Greek Constitution contains nine articles with references to political parties. Art. 29 is clearly the most important for their constitutional status, since it declares the freedom of formation of political parties and their functioning according to democratic principles. In 2001 an amendment was introduced with the aim of extending public funding to the political parties' operational expenses. Further articles refer to political parties in the government formation and dismissal, with regard to their role in the parliamentary assembly and ruling their access to public media for electoral campaigns.

Greece belongs to the States which have not passed a specific political parties law so far. In the electoral law there are references to the public role of political parties, which are described as subjects committed to carrying out their political functions through democratic means. Between 2002 and 2004, the last amendments to the regulation on public funding of political parties were introduced. The 2002 party finance law regulates the funding of political parties for both operational activities and electoral expenses ${ }^{47}$. The first source of finance is granted to those parties which are represented in parliament as well as to those political parties who competed at the latest parliamentary elections in at least 70 percent of electoral districts obtaining at least 1.5 percent of the votes. The latter are recognized with the same criteria as parties for their campaigns regarding national and European elections.

\footnotetext{
46. According to article 18 of Party Law, state funding to political parties is provided to those parties obtaining at least 0.5 per cent of the valid votes at the most recent European or Bundestag elections, or obtaining at least 1 per cent of votes at one of the most recent elections for a regional parliament (Landtag).

47. LAW 3023/2002 (OG A 146 20020625) Funding of Political Parties by the State Income and Expenditure, Promotion, Advertising and Financial Auditing of Political Parties and Parliament Candidates, copyrighted translations, avail. at: www.partylaw.leidenuniv.nl, Source: http://www.drassi.gr/ sre_files/2002_3023.pdf [last access 11.3.2015].
} 


\subsection{Italy}

The Italian Constitution of 1948 refers to political parties in three articles. It establishes the right of all citizens "to associate freely in political parties in order to contribute by democratic means to the determination of national policy" (art. 49), the incompatibility of party membership with activity in the judiciary, in the armed forces and in diplomatic and in consular representation organs abroad (art. 98), and prohibits the reconstruction of the fascist party (XII transitory and final provisions). The wording of art. 49, which was the result of a long internal discussion between the different political streams composing the Constitutional Assembly, has often been criticized by Italian constitutionalists for its ambiguity and for lacking prescriptive significance. However, unanimous agreement exists that the way in which art. 49 is formulated avoids placing any legal regulation on political parties, which therefore remain considered in Italy as private voluntary associations with no juridical status or personality.

Despite a long debate about the necessity to introduce a specific regulation of political parties, the Italian Parliament has never passed a specific party law, opting for several provisions regarding public finance of political movements. After the first bill, approved in 1974, many other statutes have followed, always providing some form of public finance or reimbursement for electoral expenses. After a referendum in 1993, Italian political parties benefitted only from the reimbursement of electoral campaigns, which however has been extended to both local level and European Elections. Also, the sum being reimbursed increased impressively in the 1990s, leading to an actual restoration of the pre-1993 figures. Moreover, since 1999 an annual lump sum has been distributed for the relevant elections, independently from the parties' actual expenses ${ }^{48}$. The new government, in power since 22 February 2014, recently approved a reform which cuts public finance to political parties ${ }^{49}$, and entered into force on 27 February 2014.

According to the new regulation, from 2017 onwards, political parties will only be able to count on private donations. Besides, citizens can decide to give 0.002 percent of their income tax to their preferred party, provided that the party will approve a statute. The statute must specify the number and composition of the internal bodies of the party, and explain the mode of their election. It will also report the timing of congressional meetings, as well as the procedures for the approval of the acts that bind the party. In the statute, there must also be given the methods of selection of candidates, and the criteria to ensure the presence of minorities in the party's bodies with non-executive competences. A Guarantee Commission will monitor the compliance of the statutes with the new regulation and may request changes. In order to take advantage of voluntary private funding as well as of a more favorable tax regime, the parties must respect two basic conditions: firstly, they must be inscribed in an ad hoc register of political parties, open only to those political movements which respect the organization rules foreseen in the new law. Secondly, they must have at least one candidate elected under its own symbol in the last elections for the national Parliament, the European Parliament or a regional council, or have submitted in the same election candidates in at least three constituencies for the renewal of the Chamber of Deputies or in at least three regions for the renewal of the

48. L. 3 June 199, nr. 157, avail. at http://www.camera.it/parlam/leggi/99157l.htm [last access 11.3.2015].

49. L. 21 February 2014, nr. 13, which converted the Decree issued by the Government in December 2013, avail. at: http://www.normattiva.it/uri-res/N2Ls?urn:nir:stato:legge:2014;13 [last access 11.3.2015]. 
Senate, or in a regional council or autonomous province, or in at least one constituency for the election of Members of the European Parliament.

\section{8, United Kingdom}

The Registration of Political Parties Act, issued in $1988^{50}$, was the first law on political parties in the UK. On the one hand, the Act established a system for registration of party names and emblems; on the other hand, even if party registration was not compulsory, the Act provided a number of benefits for parties to register, like the right to have access to political broadcasts.

The Act of 1988 did not provide further regulation of party financing. It was an ad hoc 'Committee on Standards in Public Life', established by the British Government in 1994, which recommended some provisions which became the legal basis for the enactment of the 2000 Political Parties, Elections and Referendum Act ${ }^{51}$. The Act established an independent Electoral Commission with the function of holding and supervising the registration of political parties, as well as of controlling the parties' incomes and expenditures. Political parties were therefore required to provide an audited annual account of incomes and expenditures to the Electoral Commission. In addition, important limitations and controls over the financial activities of political parties were introduced: the Act prohibited foreign donations and anonymous donations of over $£ 200$, and established limits in the parties' campaign expenditures.

The 2009 Political Parties and Elections Act ${ }^{52}$ further strengthened the regulatory powers of the Electoral Commission, which was thus provided with new powers of investigation and was entitled to impose civil sanctions against parties which violated the current regulation. Today, political parties in the UK are entitled to receive both direct contributions (financial aids), and indirect contributions (further practical benefits like free broadcasting time, free postal delivery, free use of public halls).

\section{Anti-Euro parties in the European Elections 2014}

An very helpful way to verify which level of consent Anti-Euro Parties currently enjoy in their countries is to analyze the results gained by those movements in the European elections held in May 2014. With the only exceptions of Austrian Team Stronach ${ }^{53}$, in fact, all other parties took part in the competition: their results at the polls are summarized in Table 1.

\footnotetext{
50. Available at: http://www.legislation.gov.uk/ukpga/1998/48/contents [last access 11.3.2015].

51. Available at: http://www.legislation.gov.uk/ukpga/2000/41 [last access 11.3.2015].

52. Avail. at: http://www.legislation.gov.uk/ukpga/2009/12/contents [last access 11.3.2015].

53. Kathrin Nachbaur, President of the Stronach's parliamentary group in the Austrian National Council, justify the party's refusal to run for European Elections with the aim to concentrate on the forthcoming national and regional elections, «Katrin Burgstaller, Nachbauer: Die Neos sind ein moderner Männerklub», in: derStandard.de, avail. at http://derstandard.at/1395364606981/Nachbaur-Die-Neos-sind-ein-moderner-Maennerklub [last access 11.3.2015].
} 


\begin{tabular}{|l|l|c|c|c|}
\hline \multicolumn{5}{|c|}{ Table 1: Anti-Euro Parties, Results European Elections 2014 } \\
\hline \multicolumn{1}{|c|}{ Party } & Country & $\% /$ Seats & Variation 2009 & Nat. Turnout (\%) \\
\hline The Finns & Finland & $12.9 / 2$ & $+3.1 /+1$ & 41 \\
\hline Front National & France & $24.7 / 23$ & $+18.4 /+20$ & 42.4 \\
\hline Dracma Five Stars & Greece & $0.1 /-$ & New & 60 \\
\hline Plan B & Greece & $0.2 /-$ & New & " \\
\hline $\begin{array}{l}\text { Alternative für } \\
\text { Deutschland }\end{array}$ & Germany & $7.1 / 7$ & New & 48.1 \\
\hline Piratenpartei & Germany & $1.4 / 1$ & $+0.5 /-$ & " \\
\hline Movimento 5 Stelle & Italy & $21.1 / 17$ & New & 57.2 \\
\hline $\begin{array}{l}\text { United Kingdom } \\
\text { Independent Party }\end{array}$ & $\begin{array}{l}\text { Un i t e d } \\
\text { Kingdom }\end{array}$ & $26.8 / 24$ & $+9.9 /+9$ & 35.4 \\
\hline
\end{tabular}

Source: European Parliament

Despite of some similarities in their electoral strategy, mainly concentrated on a strong criticism against Euro currency, European economic provisions and European integration process, the level of votes gained by Anti-Euro parties resulted very different. A very surprising exploit was achieved by French Front National, British UKIP and Italian Movimento 5 Stelle: each of them cast over 20 per cent of preferences, the French and the British movements were the most voted lists in their country, while Grillo's party was the second political force in the European elections in Italy. Even if the level of discontent against the European boundaries had been increasing in the months preceding the elections in these countries, only few analysts expected French, British and Italians Anti-Euro movements to gain popular consent in such a measure.

A relevant result came also for German Anti-Euro movements, although with consistent difference: on the one hand, the absolute newcomer Alternative für Deutschland achieved a remarkable $7.1 \%$ of the votes, which can be considered an astonishing score, with the party created only in February 2013 able to gain consent from 2,070,014 German voters ${ }^{54}$; on the other hand, the German Pirates - second political force in the country following a European critical approach - was not able to attract political consent in the same measure as AfD and obtained only $1.4 \%$ of the votes. Indeed, differently from AfD, Pirates' anti-European positions concentrated on the lack of democracy of the recently adopted European Stability Mechanism (ESM) provisions, rather than on the European Currency or the European integration process as a whole ${ }^{55}$ : this could explain why German Euro-sceptics preferred to vote for AfD, which based its campaign almost exclusively on the consequences of the ESM and European Monetary policies for the German national finances.

The Finns, which based their electoral campaign on anti-immigrations policies, gained $12.9 \%$ of the votes: a satisfying result, but not sufficient to match the success they had

54. Source: Bundeswahlleiter, s. http://www.bundeswahlleiter.de/de/europawahlen/EU_BUND_14/ ergebnisse/bundesergebnisse/ [last access 11.3.2015].

55. Piraten gegen Unterzeichnung des umstrittenes ESM-Vertrags, avail. at: https://www.piratenpartei. de/2012/06/29/piraten-gegen-unterzeichnung-des-umstrittenen-esm-vertrags/ [last access 11.3.2015]. 
obtained in the 2011 national elections, when they achieved 19\% of preferences ${ }^{56}$. Also in this case, this result could be due to the success achieved by the National Conservative Party, which managed to remain the strongest Finnish political force and attracted at least part of the voters disappointed with the effects of the European boundaries for the national political and economic conditions.

At last, Dracma Five Stars and Plan B completely failed in intercepting the extremely spread anti-European feelings of Greek voters, who ignored them and rather preferred to express their frustration against Europe giving massive support to leftwing party Syriza, which adopted a very similar strategy in its electoral campaign, nevertheless proving to be much more persuasive and successful ${ }^{57}$.

\section{Conclusions: Does party regulation impact on the electoral performance of Anti-Euro parties?}

Despite the fact that the political parties considered in this analysis show a basic common characteristic, which is their strict refusal of the economic European boundaries in their own national system, nevertheless they present several very relevant differences in terms of organization, political messages, electoral strategies and public communication. In such a short contribution it is not possible to provide a reliable comparison of such varied political movements, and it must also be noted that party laws are certainly not the only factor which can influence how parties perform in elections: the electoral system itself plays a probably even more essential role. It seems however reasonable to reflect on the electoral success recently achieved by the above-mentioned parties, and to relate it to the type of political parties' regulation applying in the different national contexts.

Although the relationship is not immediately obvious, this brief analysis shows that Anti-Euro parties tend to be more successful in countries which are not provided with a strict party regulation. In Austria, France, Greece, Italy and United Kingdom, where only parties' financing is ruled upon, Anti-Euro parties seem to have an advantage over those in countries like, for example, Germany. There, even a brand new political movement like AfD, which made Euro-criticism the single issue of its campaign, did not manage to gain seats in the national Parliament. An exception can be seen in Finland, where The Finns managed to gain a stable and consistent level of consent despite a very detailed law which set down harsh rules about parties' organization and obligations. However, the Finnish Anti-Euro party was founded in 1995, and therefore had much more time than the most recent political movements to enforce its appeal in the eyes of the Finnish voters. A similar objection can be seen in the case of the Front National in France: a party which is over 40 years old, and which only recently

56. Spiegel.de, Brussels' Fear of the True Finns: Rise of Populist Parties Pushes Europe to the Right (25 April 2011), avail. at: http://www.spiegel.de/international/europe/brussels-fear-of-the-true-finns-rise-ofpopulist-parties-pushes-europe-to-the-right-a-758883.html [last access 11.3.2015].

57. H Smith, «Leftwing Syriza party triumphs in European elections in Greece», The Guardian 26 May 2014, avail. at: http://www.theguardian.com/politics/2014/may/26/syriza-european-elections-greece [last access 11.3 .2015$]$. 
showed significant chances of success after a change in the leadership and after having adopted a strong anti-Euro strategy.

A clear example of the influence of party regulation comes from the comparison between the German Pirate Party and the Italian Five Stars Movement. Despite the fact that the two parties are extremely similar in terms of political aims, communication strategies, the use of the Internet and social media for their internal organization, the German movement has suffered a deep loss of votes since 2012, and the last opinion polls do not show an improvement for the future. Instead, the Movimento 5 Stelle not only gained over 25 percent of preferences at the 2013 general elections, but seems to be able to confirm this trend also in the coming European elections of May 2014. It is possible to assume that the hard conditions laid down by the Parteiengesetz in Germany have imposed a significant system of legal provisions which every political subject must observe if it wants to have the right to exist as a party. On the other hand, the lack of a party law in Italy has allowed the Five Stars Movement and its leader Grillo to adopt initiatives and to enact campaign strategies very likely to be forbidden in Germany, and the surveys show that the unconventional tactics embraced by Grillo have attracted large parts of the Italian electorate in the last years.

The final consideration in this brief analysis is therefore that party laws are surely not the only element which affects the electoral fortune of political parties: electoral systems and party finance regulations also play an undisputedly crucial role. For the very special kind of political movements such as the recently established anti-Euro parties, however, the existence or absence of specific party law can make the difference between a significant electoral success and a lack of popular support. Notoriously, new parties need time, energy and resources to gain the attention of the electorate and to convince people to change their political preferences ${ }^{58}$. Political newcomers are more likely to break traditional schemes and look for nonconformist communication strategies and political issues, in order to fill the gap of consideration already paid by media, institutions and public opinion to traditional political parties. Therefore, a strict organization model requested by law in order to take part in electoral campaigns, to take advantage of public benefits, or even to simply be allowed to officially exist as a political party, can significantly restrict the unconventional approach adoptable by anti-Euro parties and consequently reduce their chances of success at the polls ${ }^{59}$. Besides, their major "single-issue" strategy does not usually help them to keep the attention of the electorate for long terms. We can thus conclude that party regulation can significantly affect the political performance of newcomers like the anti-Euro parties, although it is still too soon to provide an exact measure of this influence so far. It is reasonable to consider the opportunity of extending and deepening this investigation, and as such, this work should be considered as a first step in this direction.

58. I Lago/F Martínez, «Why new Parties?», 17 Party Politics, (2011), pp 3-20.

59. I van Biezen/E R. Rashkova, «Deterring new party entry? The impact of state regulation on the permeability of party systems», 18 Party Politics (2012), avail. at: http://ppq.sagepub.com/content/early/2012/09/23/1354068812458616 [last access 11.3.2015]. 


\section{Reference}

D Arter, «Taking the Gilt of the Conservatives' Gingerbread: The April 2011 Finnish General Elections», 34 West European Politics (2011), pp 1284-1295

D Arter, «Analysing "Successor Parties": The Case of the True Finns» 35 West European Politics (2012), pp 803-825

M Balent, «The French National Front from Jean-Marie to Marine Le Pen: Between Change and Continuity», in: K Grabow/F. Hartleb (eds.), Exposing the Demagogues. Right-Wing and National Populist Parties in Europe, Konrad Adenauer Stiftung/Center for European Studies (2013), pp 160-186

H Bartels, «Die Vorgeschichte: die Urheberrechtsdebatte und die schwedische Piratpartiet», in: O Niedermayer (ed.), Die Piratenpartei, Heidelberg, Springer (2013), pp 15-28

J Bartlett/C Froio/M Littler/D McDonnell, «Social media is changing politics across Europe... New political Actors in Europe: Beppe Grillo and the M5S», London, Demos (2013)

B Beauzamy, «Explaining the Rise of the Front National to Electoral Prominence: Multi-Faceted or Contradictory Models?», in: R Wodak/M KhosraviNik/B Mral (ed.), Right-Wing Populism in Europe: Politics and Discourse, London/New York, Bloomsbury (2013), pp 177-190

R Biorcio/P Natale, Politica a 5 Stelle. Idee, storia e strategie del movimento di Grillo, Milano, Feltrinelli (2013), pp 77-98

S Bukow/T Poguntke, «Innerparteiliche Organisation und Willensbildung», in: O. Niedermayer (ed.), Handbuch Parteienforschung, Heidelberg, Springer (2013), pp 179-209

F Decker, «Das Parteiensystem vor und nach der Bundestagswahl 2013», 11 Zeitschrift für Staats- und Europawissenschaften, (2013), pp 323-342

R Ford/M Goodwin, Revolt on the Right. Explaining support for the radical right in Britain, London and New York, Routledge (2014).

E Gamperl, «Europas neue Anti-Parteien», Zeit Online, 23/3/2013

K Grabow/F Hartleb, Europe - No, thanks? Study on the Rise of Right-Wing and National Populist Parties in Europe, Konrad Adenauer Stiftung/Center for European Studies, 2014

B Jouan, «Financing of political parties and electoral campaigns in France. The role of the French National Commission on campaign accounts and Political Party Financing (CNCCFP)», Legal service - CNCCFP 
C Koschmieder, «Die Piratenfraktion im Berliner Abgeordnetenhaus», in: O Niedermayer (ed.), Die Piratenpartei, Heidelberg, Springer (2013), pp 213-235

I Lago/F Martínez, «Why new Parties?», 17 Party Politics, (2011), pp 3-20

S Lenzhofer, «Die neue Parteienfinanzierung: Mehr Transparenz im Tausch gegen höhere staatliche Zuwendungen»

C. Mars, «The Rise of Right-wing Populism in Finnland: The True Finns», Transform! $8 / 2011$

M Mavrozaharakis/S Tzagkarakis/A Kamekis, «Greek Modern Populism in its European Context», Open Democracy, 4 November 2013

L Mosca/C Vaccari, «Il Movimento e la Rete», in: P Corbetta/E Gualmini (ed.), Il Partito di Grillo, Bologna, Il Mulino (2013), pp 169-196.

S Müller, «Die Kosten der Korruption», Zeit Online 12 April 2012

G Passarelli/F Tronconi/D Tuorto, «Dentro il Movimentoः organizzazione, attivisti e programmi», in: P Corbetta/E Gualmini (ed.), Il Partito di Grillo, Bologna, Il Mulino (2013), pp 123-167;

T Raunio, «The Finns: Filling a Gap in the Party System», in: K Grabow/F. Hartleb (eds.), Exposing the Demagogues. Right-Wing and National Populist Parties in Europe, Konrad Adenauer Stiftung/Center for European Studies (2013), pp 133-160

G Santoro, Un Grillo qualunque. Il Movimento 5 Stelle e il populismo digitale nella crisi dei partiti italiani, 2nd ed., Roma, Castelvecchi, (2013) pp 37-79

J G Shields, The extreme right in France: from Pétain to Le Pen, London, Routledge (2007)

M Seemann, «Plattformneutralität - das politische Denken der Piraten», inः C Bieber/C Leggewie (ed.), Unter Piraten. Erkundungen in einer neuen politischen Arena, Bielefeld, Transcript (2012), pp 91-99.

D Siemens, «No Experiments? The German Federal Elections 2013», University College London, European Studies

H Smith, «Leftwing Syriza party triumphs in European elections in Greece», The Guardian 26 May 2014

«True Finns publish Election Manifesto», 25 February 2011 
R Vignati, «Beppe Grillo: dalla Tv ai palasport, dal blog al Movimento», in: P Corbetta/E Gualmini (ed.), Il Partito di Grillo, Bologna, Il Mulino (2013), pp 29-63

I van Biezen/E R. Rashkova, «Deterring new party entry? The impact of state regulation on the permeability of party systems», 18 Party Politics (2012)

N Watt, «Ukip in fresh Nazi row after candidate Photoshops Hitler image», The Guardian, 1 May 2013 
Recebido em: 26/02/2015

Aceito em: 06/04/2015

\section{Como citar}

DE PETRIS, Andrea. Party regulation and electoral success: the case of anti-euro movements. Ballot. Rio de Janeiro: UERJ. Volume 1 Número 1 Junho 2015. pp. 21-44. Disponível em: [http://www.e-publicacoes.uerj.br/ index.php/ballot]

\section{(c) (1)(2)}

A Revista Ballot está licenciada sob uma licença Creative Commons Atribuição - Não Comercial - Compartilha Igual 3.0 Não Adaptada. 